\title{
Letter to the Editors regarding the article "Patellar resurfacing in primary total knee arthroplasty: a meta-analysis of randomized controlled trials"
}

\author{
Zhong-min Fu' ${ }^{1}$ Xiu-mei Tang ${ }^{1}$, Duan Wang ${ }^{2}$, Ning Ning ${ }^{1 *}$ and Zong-ke Zhou ${ }^{2}$
}

To the Editor:

We read with great interest in the article by Chen et al. [1] regarding the "Patellar resurfacing versus nonresurfacing in total knee arthroplasty: an updated meta-analysis of randomized controlled trials". We congratulate the authors for publishing their study in this journal. Coincidentally, we did a systematic review on the same topic in December 2020. We appreciate the interesting observation of Chen's conclusion, and after reading their article, we would like to provide our results for discussion and highlight the difference that remains exploring.

First, the authors searched electronic databases (MEDLINE, Ovid, and Cochrane Library databases), but other unpublished databases like grey literature, which may have more eligible studies were not included. In their study, 32 randomized controlled trials (RCTs) with 6887 knees were analyzed while a total of 52 RCTs (6066 in the patellar resurfacing (PR) group; 7180 in the non-patellar resurfacing (NPR) group) were reported in ours. In their article, Knee Injury and Osteoarthritis Outcome Score (KOOS), Knee Society Score (KSS), function score, noise, revision rate, anterior knee pain (AKP), visual analog score (VAS), range of motion (ROM), Oxford score, Feller score, and patient satisfaction were reported. In our study, surgery length, blood loss, complications (including patellar clunk, patellar crepitus), mortality, and cost-effective analysis were supplied. They did subgroup analysis and divided the patients into two groups: $(1) \leq 3$ years and $(2) \geq 5$ years. While in our study, subgroup analysis based on short-term results (<1 year), middle-term ( 2 to 5 years), and long-term results (6 to 10 years) were reported, and diagnosis-based subgroup analysis was also used.

Second, there existed some difference between the results of Chen and us. the author concluded that the PR group reduced the occurrence of reoperation and noise after surgery, and improved the KSS function scores, while no significant difference in AKP, ROM, Oxford score, KOOS, VAS, Feller score, patellar tilt angle, and the patient satisfaction was found. However, in our study, similar to Teel et al. [2], KSS was not influenced by the two techniques. We also found that the event of AKP was similar in the subgroup of patients with osteoarthritis (OA), while higher in the NPR group in patients with rheumatoid arthritis (RA). Subgroup analysis based on follow-up points found that the PR group had higher KSS scores than the NPR group within 1 year, between 2 and 5 years, while no difference between 6 and 10 years. It suggested the PR group might be more cost-saving than NPR in the short to long term [3-5].

\footnotetext{
* Correspondence: ningning6405@163.com

${ }^{1}$ West China School of Nursing/Department of orthopedics, West China Hospital, Sichuan University, Chengdu 610041, People's Republic of China Full list of author information is available at the end of the article
}

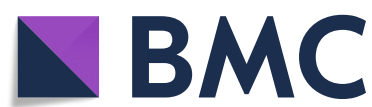

(c) The Author(s). 2021 Open Access This article is licensed under a Creative Commons Attribution 4.0 International License, which permits use, sharing, adaptation, distribution and reproduction in any medium or format, as long as you give appropriate credit to the original author(s) and the source, provide a link to the Creative Commons licence, and indicate if changes were made. The images or other third party material in this article are included in the article's Creative Commons licence, unless indicated otherwise in a credit line to the material. If material is not included in the article's Creative Commons licence and your intended use is not permitted by statutory regulation or exceeds the permitted use, you will need to obtain permission directly from the copyright holder. To view a copy of this licence, visit http://creativecommons.org/licenses/by/4.0/. The Creative Commons Public Domain Dedication waiver (http://creativecommons.org/publicdomain/zero/1.0/) applies to the data made available in this article, unless otherwise stated in a credit line to the data. 
Finally, the author pointed out the limitations of their literature without discussed the selective patellar resurfacing (SPR) which is drawing people's attention now due to the lack of prospective RCTs. Selective resurfacing may be the main trend in the future which requires more researches on this topic [6]. What is more, a cost-effective analysis was also needed to clarify the benefit of PR in the future [3].

We congratulate the authors for sharing another unique idea again. These results can guide surgeons in making optimal clinical decisions.

\section{Abbreviations}

PR: Patellar resurfacing; NPR: Non-patellar resurfacing; KOOS: Knee Injury and Osteoarthritis Outcome Score; KSS: Knee Society Score; AKP: Anterior knee pain; VAS: Visual analog scale; ROM: Range of motion; OA: Osteoarthritis; RA: Rheumatoid arthritis

\section{Acknowledgements}

None

\section{Authors' contributions}

FZM, TXM, and WD wrote this manuscript. NN and ZZK reviewed the selected studies in Chen et al.'s review. All authors read and approved the final manuscript.

\section{Funding}

Supported by Sichuan Science and Technology Program (No.2019YJ0031).

Ethics approval and consent to participate

Not applicable

\section{Consent for publication}

Not applicable

\section{Competing interests}

The authors declare that they have no competing interests.

\section{Author details}

${ }^{1}$ West China School of Nursing/Department of orthopedics, West China Hospital, Sichuan University, Chengdu 610041, People's Republic of China. ${ }^{2}$ Department of Orthopedics, West China Hospital/West China School of Medicine, Sichuan University, Chengdu 610041, People's Republic of China.

Received: 10 February 2021 Accepted: 17 February 2021

Published online: 02 March 2021

\section{References}

1. Chen $\mathrm{K}$, et al. Patellar resurfacing versus nonresurfacing in total knee arthroplasty: an updated meta-analysis of randomized controlled trials. J Orthop Surg Res. 2021;16(1):83.

2. Teel AJ, et al. Patellar resurfacing in primary total knee arthroplasty: a metaanalysis of randomized controlled trials. J Arthroplast. 2019;34(12):3124-32.

3. Zmistowski BM, et al. Routine patellar resurfacing during total knee arthroplasty is not cost-effective in patients without patellar arthritis. J Arthroplast. 2019;34(9):1963-8.

4. Kamaraj A, et al. Modelling the cost-effectiveness of total knee arthroplasty: A systematic review. J Orthop. 2020;Date of Publication:01 Nov 2020.

5. Meijer KA, Dasa V. Is resurfacing the patella cheaper? An economic analysis of evidence based medicine on patellar resurfacing. Knee. 2015;22(2):136-41.

6. Vertullo $\mathrm{CJ}$, et al. The effect of surgeon preference for selective patellar resurfacing on revision risk in total knee replacement: an instrumental variable analysis of 136,116 procedures from the Australian Orthopaedic Association National Joint Replacement Registry. J Bone Joint Surg Am. 2019;101(14):1261-70.

\section{Publisher's Note}

Springer Nature remains neutral with regard to jurisdictional claims in published maps and institutional affiliations.
Ready to submit your research? Choose BMC and benefit from:

- fast, convenient online submission

- thorough peer review by experienced researchers in your field

- rapid publication on acceptance

- support for research data, including large and complex data types

- gold Open Access which fosters wider collaboration and increased citations

- maximum visibility for your research: over $100 \mathrm{M}$ website views per year

At BMC, research is always in progress.

Learn more biomedcentral.com/submissions 